\title{
Nutrigenomics: The Science to Unfold the Impact of GM Food on Health
}

\section{Gupta $S^{*}$}

Department of Molecular Biology and Genetic Engineering, College of Biotechnology, Sardar Vallabhbhai Patel University of Agriculture and Technology, U.P. (India)

*Corresponding Author: Shalani Gupta, Department of Molecular Biology and Genetic

\section{Review Article}

Volume 3 Issue 3

Received Date: March 19, 2018

Published Date: June 11, 2018

Engineering, College of Biotechnology, Sardar Vallabhbhai Patel University of Agriculture and Technology, U.P. (India), Tel-+91-121-2888531; Email : sgupta_mbge@yahoo.com

\section{Abstract}

After the development of second generation transgenic crops, molecular characterization of food and feed and its impact on health became imperative. The growing awareness towards the impact of modified food or diet on human health led down the foundation of nutrigenomics. Nutrigenomics is an emerging field of science that tends to unfold the role of nutrition on gene expression which brings together the science of bioinformatics, nutrition, molecular biology, genomics, epidemiology and molecular medicine. The present review focuses on origin, status, strategies and goals of Nutrigenomics research. Omics supported different techniques, which have been considered as the best research tools to study the effect of diet/ food on the genome, are also discussed in relation to Nutrigenomics. To gain deeper insight of diet- gene interaction and to develop biomarker for early prediction of diet related diseases, there is an urgent need to boost more research in the field of Nutrigenomics to help people in understanding the relationship between diet and health.

\section{Introduction}

Food security and adequate nutrition are two crucial aspects of sustainability. The advances in biotechnology and especially in molecular biology during past two decades have resulted in a new agricultural revolutionthe "Gene Revolution" which enables the production of Genetically Modified (GM) or Transgenic or Biotech crops that could play an important role in addressing hunger and increasing food security [1,2]. The global hectarage of biotech crops has increased more than 100-fold from 1.7 million hectares in 1996 to181.5 million hectares in 2014 [3]. This impressive adoption rate speaks for itself, in terms of its sustainability, resilience and the significant benefits it delivers to both small and large farmers as well as consumers.

In addition to addressing hunger through increasing production and availability of food, biotechnology may help address critical nutritional deficiencies by developing a second generation of GE crops i.e. nutritionally enhanced GE crops. These nutritionally enhanced GE crops can address nutritional requirements directly by contributing to multipoint intervention strategies [4]. Apart from offering an unrestricted choice of genes for nutritional improvement, the GE approach allows nutritional traits to be targeted to specific plant parts and multiple traits can be combined in the same 


\section{Food Science and Nutrition Technology}

plants without complex breeding programmes [5,6]. Researchers [7] claimed that genetic modification (GM) technologies are used to modify biosynthesis pathways in order to achieve increased amounts of essential macronutrients (protein, carbohydrate and lipids) and micronutrients (vitamins and minerals) of food stuffs from plant as well as animal origins to contribute in food security and health. Diet- related factors, which predominantly reflect interactions among micronutrients and other organic compounds, have a profound effect on the efficacy of a nutritionally enhanced crop [8]. Such factors include the chemical form of the nutrient $[9,10]$ leading to improved nutritional and/or health characteristics. GM plant derived food and feed, which have been obtained either through extensive genetic modifications targeted at specific alterations of metabolic pathways (such as rice containing beta-carotene, soybeans with enhanced oleic acid content, or tomato with increased concentration of flavonoids) or when a new gene producing a novel protein is introduced into a crop, there is a chance that human subpopulations may have an allergic reaction to the protein [11].

Moreover, these genetically/ metabolically engineer plants with desired quality traits in general could potentially lead to unexpected or unintended changes in concentration of toxic substances or nutrient composition of plants. Although progress in dissecting metabolic pathways and our ability to manipulate gene expression in genetically modified (GM) plants has progressed a pace, attempts to use these tools to engineer plant metabolism have not quite kept pace. The success of this approach hinges on the ability to account for the changes created by these modified dietary metabolite on host metabolism. Thus, the ultimate success of any genetic modification in plants can only be judged by its impact on human health and nutrition after deployment [12] leading to the application of these nutritionally GM products highly controversial, as many consumers remain skeptical because of socio-psychological factors associated with potential food risks.

Recent advances in molecular biology combined with the wealth of information generated by the Human Genome Project have fostered the emergence of 'Nutrigenomics'. This new wave of molecular nutrition, which unfolds the mystery behind nutrition-gene interactions, may provide the strategies for developing safe and effective nutritherapy for individuals $[13,14]$.

The Nutrigenomics study represents a novel and powerful approach in nutritional sciences which not only elucidates the underlying molecular mechanisms but also being used to determine the extent and effectiveness of the modification introduced $[15,16]$. Simultaneously, it evaluates the health and safety concerns related to the consumption of genetically modified dietary nutrients [17-19]. Nutrigenomics has the potential to impact various parts of the food chain including the genetic modification of the crops and animal feeds (Figure 1).

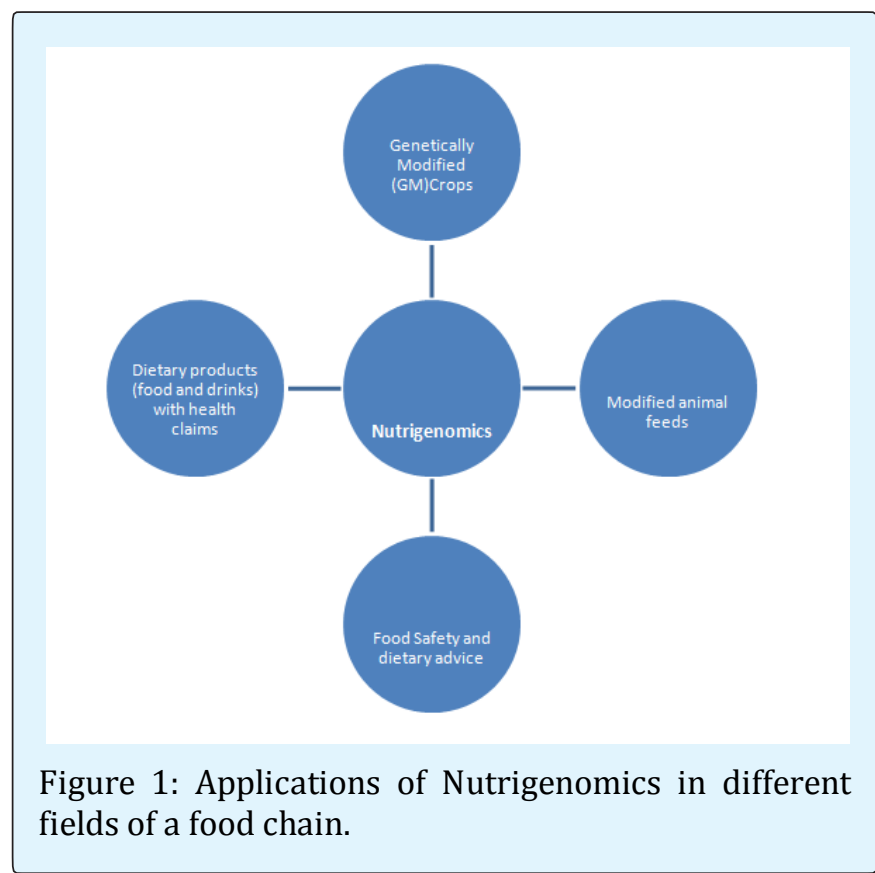

The opportunity now exists for developing countries to cuddle Nutrigenomics as a driver for sustainable agriculture. For this purpose, scientists must engage in and understand the principles and findings of Nutrigenomics. This review focuses on defining the strategies, goals and role of Nutrigenomics in health and disease prevention and related insights on how nutritionrelated biomarkers may assist in prevention of diet related disease with the help of different Nutrigenomics research tools.

\section{Nutrigenomics: Origin and Definition}

\section{Origin}

Research on nutritional area can be seen since $400 \mathrm{BC}$, when Hippocrates speculated the hypothesis that the warm body temperature was innate. In fact, Hippocrates is often quoted as suggesting "to let food be thy medicine and medicine be thy food."

The first era in nutritional research was "analytical Chemistry Era" that began around 1700 AD [20]. During 


\section{Food Science and Nutrition Technology}

this period, it was discovered that how food was metabolized by the body to generate water, carbon dioxide, and energy [21]. In 19th century, it was identified that various macromolecules as carbohydrates, proteins, lipids, etc released heat [20]. The period between the 18th and 20th centuries was called "Chemical and Analytical Era of Nutrition". During this era, important discoveries were made on food metabolism and their relation with energy production, including its relevance on breathing and oxidation [22]. The 19th century which was known as the "Biological Era", studies on metabolism and chemistry were done, helping the science of nutrition on defining their role in the development and prevention of chronic diseases, such as cancer, cardiovascular, neurodegenerative, and bone metabolism disorders [21]. Throughout the 20th century, Nutritional Science focused on finding vitamins [23] and minerals [24], defining their use and preventing the deficiency diseases [25-28] that they caused. Later, nutrition related health problems of the developed world shifted to over nutrition, obesity [29] and type- 2 diabetes [30,31], the focus of modern medicine and of Nutritional Science changed. To prevent the development of these types of disease, nutrition research is investigating on how nutrition can optimize and maintain cellular, tissue, organ and whole body homeostasis. This requires understanding how nutrients act at the molecular level which in turn involves a multitude of nutrient-related interactions at the gene, protein and metabolic levels.

Genomic Era' was started with the advances of genome sequencing and the decoding of the human genome. Soon after the completion of the first draft of the human genome in 2001 [32], nutrition research shifted to Molecular Biology and Genetics and 'Nutrigenomics' was emerged as new area of research in nutrition science [33]. By this time, the researches in nutritional research were focused on identifying and understanding molecular-level interactions between ingested nutrients, and other dietary bioactive compounds, with the genome with the expectations that in 'less than 10 years', results from Nutrigenomics studies would provide a basis for the development of safe and effective diet therapies to rationally and specifically improve health in individuals or subgroups of the population [33]. This lead the focus of Nutrigenomics towards the study of effect of nutrients on genome, transcriptomic, proteome as well as on metabolome.

The advent of 'omics' technologies have provided the tools for the understanding of diet-gene interaction at the molecular level. as Nutrigenomics involves the characterization of gene products, their physiological function and their interactions. Nutrigenomics is all about how chemical molecules in food can affect gene expression in an individual and that this influence may vary between individuals with resulting health consequences.

Nowadays, the "Post-Genomic Era" is being experienced. This era is characterized by the integration of three fields: biological, social, and environmental, where scientific discoveries on nutritional pathophysiology and metabolism are included [34,35]. Time-lines in the development of different eras of Nutrigenomics are shown in Figure 2.

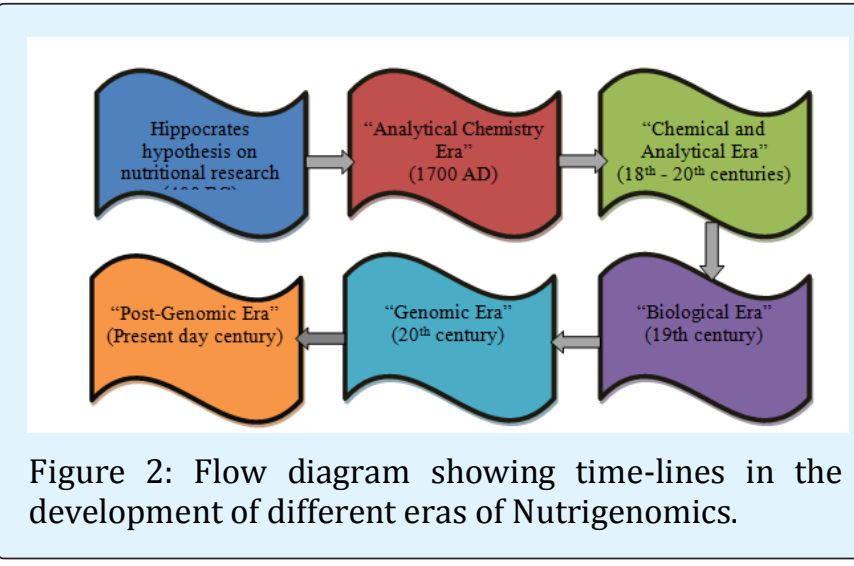

\section{Definition}

The term 'Nutrigenomics' was used in 1999 by Della Penna who defined Nutrigenomics as the general approach to the gene discovery that is currently most applicable to the compounds of nutritional importance that are synthesized or accumulated by plants or other organisms.

Later, Nutrigenomics was defined as the study of how genes and gene products interact with dietary chemicals to alter phenotype and, conversely, how genes and their products metabolize nutrients [36,37].

An international group of biologists, ethicists and sociologists [38] defined Nutrigenomics as 'a multidisciplinary approach for the comprehensive investigation of the influence of diet and individual genetic variation as risk factors for chronic diseases'.

In 2006, Mariman [39] defined Nutrigenomics as the study of the effect of nutrition or dietary components on the transcriptome of cells and tissues. 


\section{Food Science and Nutrition Technology}

Recently, Sales et al. (2014) [40] defined Nutrigenomics as an emerging science which investigates a certain area of nutrition that uses molecular tools to search, access and understand the several responses obtained through a certain diet applied between individual and population groups.

Thus, we can notice that the early definition of Nutrigenomics referred only to studies on the effects of nutrients/bioactive food on gene expression of an individual. In a molecular context, nutrients can be considered as "signalling molecules" transmitting and translating dietary signals into changes in gene, protein and metabolite expression via the appropriate cellular sensing mechanisms [41]. On a genomic level, nutrients and in turn, their dietary signals serve as "signatures". In this context, nowadays, this definition expanded and recently, Nutrigenomics seeks to understand the influence of dietary components on the Genome, Transcriptome, Proteome, and Metabolome [42-44].

\section{Concept /Inter-relationship of Nutrigenomics with Different Areas of Science}

Most foods are composed of diverse constituents, many of which have specific biological activity. Little is known about their molecular functions and the biological processes involved owing to the lack of effective analytical approaches. In addition to this, bioactive food compounds also interact with each other, making even more difficult any effort to identify their biological activities.

Nowadays, it is recognized that understanding the effect of diet on health requires the study of the mechanisms of nutrients and other bioactive food constituents at the molecular level. Nutrigenomics is the collective, scientific study of the way foods or their components interact with genes to influence phenotype of the human beings $[45,46]$. Researchers are beginning to unravel the genetic factors that influence an individual's eating behaviors and gene-diet interaction by linking different fields of basic and applied science with the Nutrigenomics studies.

An important challenge in Nutrigenomics research is the complexity and a very wide range of variability of nutrition and foods. Each nutrient has many targets and pathways not only in its own but also in combinations with other components. It is desirable to study different such aspects of dietary nutrients making it very complex. Thus, Nutrigenomics technology itself is a composite technology of basic research as well as an integrated research (molecular biology technologies, genetics, biochemistry, physiology, molecular nutrition etc), combined with multiple omic techniques (genomics, proteomics, metabolomics, transcriptomics, epigenomics and pharmacogenomics etc), to seek and explain the existing reciprocal interactions between genes and nutrients at a molecular level (Figure 3).

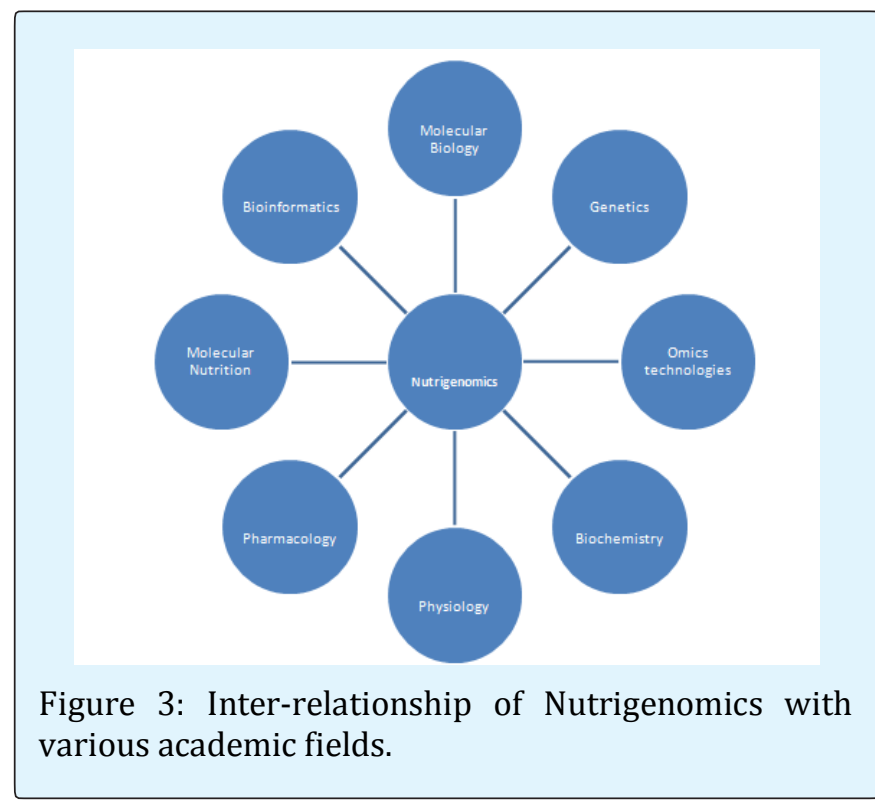

It is not worthy that most of the genomics technologies are quite expensive. Not surprisingly, an increasing number of large national and international Nutrigenomics research clusters are being formed to jointly address these and similar challenges. These clusters typically focus on specific aspects of nutrition research and disease prevention that can be approached with Nutrigenomics research. For such a collaborative effort to be successful, there must be excellent communication among scientists from different disciplines (eg, nutrition, molecular biology, medicine, genomics, bioinformatics), and there must be a high level of compatibility of the genomics data produced [13].

In the expression process of genomic information, several steps may be regulated by nutrients and other bioactive compounds in the food. On the opposite, the analysis of global gene expression may offer better opportunities to identify the effect of bioactive food constituents on metabolic pathways and homeostatic control and how this regulation is potentially altered in the development of certain chronic diseases [47]. Nutrigenomics has also been used as a basic technology that became a driving force for the creation of Nutraceutical. In this way it's having potential linkage 


\section{Food Science and Nutrition Technology}

possibilities with food and pharma industries. Until now Nutrigenomics is not investigated thoroughly and there are many fields to be researched further.

\section{Strategies and Goals of Nutrigenomics}

Nutrigenomics is defined as the combination of three complementary areas:

a) The direct relationship between nutrients and DNA to modify genetic expression.

b) Epigenetic interactions in which nutrients modify the structure of DNA (DNA methylation and chromatin remodeling), affecting gene expression, and

c) Genetic variations within humans that relate to the variations between humans in their response to diet (single nucleotide polymorphisms).

The combination of these nutrient-gene mechanisms define an individual's metabolic phenotype-measurable physical and biochemical characteristics, including nutrient status and requirements $[48,49]$.

Two different, but complementary, strategies can be used in Nutrigenomics research [13]-

a) The first strategy is the traditional hypothesis-driven approach: specific genes and proteins, the expression of which is influenced by nutrients. This strategy provides us with detailed molecular data on the interaction between nutrition and the genome. This strategy, typically applied by smaller research groups, and can allow new genes and pathways to be identified.

b) The second strategy is the SYSTEMS BIOLOGY approach: gene, protein and metabolite signatures that are associated with specific nutrients, or nutritional regimes, are catalogued. This strategy might be more important for human nutrition as this strategy is applicable to nutritional systems biology to develop biomarkers of early metabolic dysregulation and susceptibility (stress signatures) that are influenced by diet. This strategy requires large consortia, considerable research funding, and excellent multidisciplinary (and possible multinational) collaboration.

Keeping in mind the above two major strategies, the following goals of Nutrigenomics research can be defined:

a) the identification of transcription factors that function as nutrient sensors and the genes they target;

b) elucidation of the signaling pathways involved, and characterization of the main dietary signals; c) measurement and validation of cell- and organ-specific gene expression signatures of the metabolic consequences of specific micro- and macronutrients;

d) elucidation of interactions between nutrient-related regulatory pathways and pro inflammatory stress pathways, to understand the process of metabolic dysregulation that leads to diet-related diseases;

e) Identification of genotypes that are risk factors for development of diet-related human diseases (such as diabetes, hypertension, or atherosclerosis) and quantification of their impact on the genome.

f) the use of nutritional systems biology to develop biomarkers of early metabolic dysregulation and susceptibility (stress signatures) that are influenced by diet

g) Identification of new bioactive food ingredients, and to validate the effectiveness of these bioactive ingredients as functional food components or Nutraceutical.

h) studying the genetic difference in dietary response, as a basis for developing the concept of "personalized diets,

i) matching the nutrient intake combination (i.e. nutriome,) with the genome profile so that DNA integrity, gene expression, metabolism and cell function can occur normally and in a homeostatic ally sustainable manner.

j) provide better mechanistic interpretation of data from epidemiological and clinical intervention studies regarding health impacts of dietary factors that may help to refine recommendations so that they can also be specifically targeted to individuals and genetic subgroups.

However, Hisanori Kato [50] defined only two major goals of Nutrigenomics in broader sense -

a) To make full use of genomic information to reveal how genetic variations affect nutrients and other food factors and thereby realize tailor-made nutrition (nutrigenetics).

b) To comprehensively understand the response of the body to diets and food factors through various "omics" technologies.

\section{Nutrigenomics and Diet-Gene Interaction}

The Numerous dietary components can alter genetic events, and thereby influence health. In addition to the essential nutrients, such as carbohydrates, amino acids, fatty acids, calcium, zinc, selenium, folate, and vitamin A, $\mathrm{B}, \mathrm{C}, \mathrm{D}$ and $\mathrm{E}$, there is a variety of nonessential bioactive components that seem to significantly influence health $[51,46]$. Examples of these phytochemicals are listed in Table 1. 


\section{Food Science and Nutrition Technology}

\begin{tabular}{|c|c|c|}
\hline Class/Component & Source & Potential Health Benefit \\
\hline \multicolumn{3}{|c|}{ Carotenoids } \\
\hline$\alpha$-Carotene & Carrot & Neutralizes free radicals that may cause damage to cells \\
\hline$\beta$-Carotene & Various fruits, vegetables & Neutralizes free radicals \\
\hline Lutein & Green vegetables & Contributes to maintenance of healthy vision \\
\hline Lycopene & $\begin{array}{l}\text { Tomato and tomato products } \\
\text { (ketchup, sauces) }\end{array}$ & May reduce risk of prostate cancer \\
\hline Zeaxanthin & Eggs, citrus, maize & Contributes to maintenance of healthy vision \\
\hline \multicolumn{3}{|c|}{ Dietary fiber } \\
\hline Insoluble fiber & Wheat bran & May reduce risk of breast and/or colon cancer \\
\hline$\beta$-Glucan ${ }^{\mathrm{a}}$ & Oat & May reduce risk of cardiovascular disease (CVD) \\
\hline Soluble fiber ${ }^{\mathrm{a}}$ & Psyllium & May reduce risk of CVD \\
\hline Whole grain ${ }^{\mathrm{a}}$ & Cereal grains & May reduce risk of CVD \\
\hline Collagen hydrolysate & Gelatin & $\begin{array}{l}\text { May help improve some symptoms associated with } \\
\text { osteoarthritis }\end{array}$ \\
\hline \multicolumn{3}{|c|}{ Fatty acids } \\
\hline $\begin{array}{l}\omega-3 \text { fatty acids } \\
\text { (DHA/EPA) }\end{array}$ & Tuna fish and marine oils & $\begin{array}{l}\text { May reduce risk of CVD and improve mental and visual } \\
\text { functions }\end{array}$ \\
\hline Conjugated linoleic acid & Cheese, meat products & $\begin{array}{l}\text { May improve body composition, may decrease risk of } \\
\text { certain cancers }\end{array}$ \\
\hline GLA & Borage, evening primrose & $\begin{array}{l}\text { May reduce inflammation risk of cancer and CVD, may } \\
\text { improve body composition }\end{array}$ \\
\hline \multicolumn{3}{|c|}{ Flavonoids } \\
\hline Anthocyanidins: cyanidin & Berries & Neutralize free radicals, may reduce risk of cancer \\
\hline Hydroxycinnamates & Wheat & $\begin{array}{l}\text { Antioxidant-like activities, may reduce risk of degenerative } \\
\text { diseases }\end{array}$ \\
\hline $\begin{array}{l}\text { Flavanols: catechins, } \\
\text { tannins }\end{array}$ & $\begin{array}{l}\text { Tea (green, catechins; black, } \\
\text { tannins) }\end{array}$ & Neutralize free radicals, may reduce risk of cancer \\
\hline Flavanones & Citrus & Neutralize free radicals, may reduce risk of cancer \\
\hline Flavones: quercetin & Fruits/vegetables & Neutralize free radicals, may reduce risk of cancer \\
\hline \multicolumn{3}{|c|}{ Glucosinolates, indoles, isothiocyanates } \\
\hline Sulforaphane & $\begin{array}{l}\text { Cruciferous vegetables (broccoli, } \\
\text { kale), horseradish }\end{array}$ & Neutralizes free radicals, may reduce risk of cancer \\
\hline \multicolumn{3}{|c|}{ Phenolics } \\
\hline Stilbenes (resveratrol) & Grape & $\begin{array}{l}\text { May reduce risk of degenerative diseases, heart disease, and } \\
\text { cancer, may have longevity effect }\end{array}$ \\
\hline Caffeic acid, ferulic acid & Fruits, vegetables, citrus & $\begin{array}{l}\text { Antioxidant-like activities, may reduce risk of degenerative } \\
\text { diseases, heart disease, and eye disease }\end{array}$ \\
\hline
\end{tabular}




\section{Food Science and Nutrition Technology}

\begin{tabular}{|c|c|c|}
\hline Class/Component & Source & Potential Health Benefit \\
\hline Epicatechin & Cacao & $\begin{array}{c}\text { Antioxidant-like activities, may reduce risk of degenerative } \\
\text { diseases and heart disease }\end{array}$ \\
\hline \multicolumn{3}{|c|}{ Plant stanols/sterols } \\
\hline Stanol/sterol estera & Maize, soy, wheat, wood oils & $\begin{array}{l}\text { May reduce risk of coronary heart disease by lowering blood } \\
\text { cholesterol levels }\end{array}$ \\
\hline \multicolumn{3}{|c|}{ Prebiotic/probiotics } \\
\hline $\begin{array}{l}\text { Fructans, inulins, fructo- } \\
\text { oligosaccharides }\end{array}$ & $\begin{array}{l}\text { Jerusalem artichoke, shallot, onion } \\
\text { powder }\end{array}$ & May improve gastrointestinal health \\
\hline Lactobacillus & Yogurt, other dairy & May improve gastrointestinal health \\
\hline Saponins & $\begin{array}{l}\text { Soybean, soy foods, soy protein- } \\
\text { containing foods }\end{array}$ & May lower LDL cholesterol, contains anticancer enzymes \\
\hline Soybean protein & Soybean and soy-based foods & $25 \mathrm{~g} \mathrm{~d}^{-1}$ may reduce risk of heart disease \\
\hline \multicolumn{3}{|c|}{ Phytoestrogens } \\
\hline $\begin{array}{l}\text { Isoflavones (daidzein, } \\
\text { genistein) }\end{array}$ & Soybean and soy-based foods & $\begin{array}{l}\text { May reduce menopause symptoms, such as hot flashes, may } \\
\text { reduce osteoporosis and CVD }\end{array}$ \\
\hline Lignans & Flax, rye, vegetables & $\begin{array}{l}\text { May protect against heart disease and some cancers, may } \\
\text { lower LDL cholesterol, total cholesterol, and triglycerides }\end{array}$ \\
\hline \multicolumn{3}{|c|}{ Sulfides/thiols } \\
\hline Diallyl sulfide & Onion, garlic, olive, leek, scallion & $\begin{array}{l}\text { May lower LDL cholesterol, helps to maintain healthy } \\
\text { immune system }\end{array}$ \\
\hline $\begin{array}{l}\text { Allyl methyl trisulfide, } \\
\text { dithiolthiones }\end{array}$ & Cruciferous vegetables & $\begin{array}{l}\text { May lower LDL cholesterol, helps to maintain healthy } \\
\text { immune system }\end{array}$ \\
\hline \multicolumn{3}{|c|}{ Tannins } \\
\hline Proanthocyanidins & $\begin{array}{l}\text { Cranberry, cranberry products, } \\
\text { cocoa, chocolate, black tea }\end{array}$ & $\begin{array}{c}\text { May improve urinary tract health, may reduce risk of CVD } \\
\text { and high blood pressure }\end{array}$ \\
\hline
\end{tabular}

Table 1: Examples of plant components with suggested functionality (Modified from International Life Sciences Institute [57].

U.S. Food and Drug Administration-approved health claim established for component [58].

These essential and nonessential bioactive food components are known to modify a number of cellular processes associated with health. Often bioactive food components will modify several processes simultaneously. These different nutrients and dietary chemicals have widespread direct or indirect effects on gene expression $[37,52]$ in all tissues. Their direct effects can be any one of the following type-

1) Act directly as ligands for transcription factor receptors. Transcription factors are the main agents through which nutrients influence gene expression $[13,36,53,54]$.

2) Be metabolized by primary or secondary metabolic pathways, thereby altering concentrations of substrates or intermediates involved in gene regulation or cell signaling; or

3) Alter signal transduction pathways and signaling.

The indirect effects of dietary compounds on gene expression can be manifested in a number of ways as whole compounds or as modified, metabolized, or 


\section{Food Science and Nutrition Technology}

hydrolyzed molecules (e.g., peptides). Many food components are known to influence the expression of both structural genes and transcription factors (Tfs) in humans $[55,56]$.

The expression of genetic information can be highly dependent on, and regulated by, nutrients, micronutrients, and phytochemicals found in food [59]. From a Nutrigenomics perspective nutrients/ bioactive food components are dietary signals that are detected by the cellular sensor systems that influence gene expression, protein synthesis and metabolite production $[13,36]$. From this point of view genes are dietary targets. Patterns of gene expression, protein synthesis and metabolite production in response to particular nutrients can be considered as dietary signatures. Minor change in structure of these dietary signals (saturated vs. unsaturated fatty acids, cholesterol vs. plant sterols) can have a profound influence on which sensor pathways are activated. By activating these receptors, nutrients are able to influence a wide array of specific genes and cellular functions. Nutrigenomics seeks to examine these dietary signatures in specific cells, tissues and organisms and to understand how nutrition influences homeostasis.

Nutrients can reverse or change epigenetic phenomena such as DNA methylation and histone modification thereby modifying the expression of critical genes associated with different cellular processes, including embryonic development, aging, carcinogenesis and other degenerative diseases [60]. Micronutrients and bio-active food molecules can modulate the epigenetic environment (Table 2) of body by the process of nutrient-gene interaction.

Nutrigenomics can greatly assist in this identification because it allows the genome-wide characterization of nutritional target genes. With this type of information, researchers can comprehensively understand how nutrients act and explain how diet has such an impressive effect on health and disease. Further, Nutrigenomics can prevent disease occurrences by explaining nutrient-gene interaction and designing individual specific dosage of single micronutrient or nutriome in genome health clinic.

Until recently, researchers could only look at a few preselected genes and single or simple groups of nutrients. The tools developed as a result of sequencing the human genome have enabled researchers to take a much broader view. Nutrigenomics has been introduced for the research on the interaction of the genome with its nutritional environment. This science has the potential for a finetuning of what foods and nutrients and how much an individual should eat to maintain an optimal health.

\section{Nutrigenomics and Diet -Related Diseases}

Since very long it is evident that the food or nutrients has been the main contributor to human health. The bioactive ingredients of food may turn on some genes and simultaneously turn off other set of genes involved in a disease. In doing so they are likely to contribute considerably to the food-related diseases such as obesity, diabetes and heart related diseases etc. This is in response to exposures to the nutritional factors that have the potential to promote or protect against these diet-related problems.

Nutrigenomics aims also to identify these genes those influence the risk of diet-related diseases on a genome wide scale and to understand the mechanisms that underlie these genetic predispositions. Many different types of evidences concluded from different studies (like genetic association studies, genetic- linkage studies, twin studies, admixture mapping etc) are relevant to decide whether or not nutrigenomics is likely to play a major role in the incidence of common diet-related diseases [61]. Characterizing how genetic factors modify the effects of a high plant-based diet or specific components in plant foods on human health outcome could clarify how plant high or low is plant based food.

Few examples of genes and diet related diseases areobesity, metabolic syndrome (also known as 'Syndrome $\mathrm{X}$ ' or 'insulin resistance syndrome' (IRS) that include the glucose intolerance and insulin resistance associated with increased risk of type 2 diabetes and the cholesterol levels and high blood pressure associated with increased risk of heart disease, combined with central obesity (a high body mass index), cancer, food intolerances (eg. lactose intolerance, favism, alcohol intoxication), food allergies and inflammatory diseases, osteoporosis, falls and fractures, brain diseases and neurodegenerative diseases (Alzheimer, Parkinsosn disease), vitamin and mineral deficiencies (Table 2) were well documented in a report from Genewatch by Helen Wallace [61]. Evidence derived from epidemiological studies has suggested that high fruit and vegetable intake is associated with a reduced risk of a variety of cancers [62] as well as cardiovascular disease [63]. 


\section{Food Science and Nutrition Technology}

\begin{tabular}{|c|c|c|c|}
\hline Nutrients Gene & Alteration & Deficient Diet-Disease & Potential Food Intake \\
\hline $\begin{array}{l}\text { Vitamin } A(\text { Retinol and } \\
\text { retinoic acid) }\end{array}$ & $\begin{array}{l}\text { Repression of PEPCK } \\
\text { gene }\end{array}$ & $\begin{array}{l}\text { Termination of pregnancy } \\
\text { and fetal death, VAD }\end{array}$ & $\begin{array}{l}\text { Carrots, spinach, turnip, kale, apricots, } \\
\text { Cantaloupe, bell pepper, Papaya, mango, } \\
\text { peach, beef liver, chicken liver }\end{array}$ \\
\hline Folic acid (Vitamin B9) & $\begin{array}{c}\text { Chromosome break and } \\
\text { hampers DNA repair/ } \\
\text { methylation }\end{array}$ & $\begin{array}{c}\text { Cancer, heart disease, brain } \\
\text { dysfunction, male infertility, } \\
\text { leukemia }\end{array}$ & $\begin{array}{l}\text { Liver, kidney, egg yolk, asparagus pea, } \\
\text { cowpeas, lentils, peanuts, spinach, } \\
\text { beetroot, broccoli, orange }\end{array}$ \\
\hline $\begin{array}{l}\text { Vitamin B12 } \\
\text { (Cobalamin) }\end{array}$ & $\begin{array}{l}\text { Chromosome break and } \\
\text { hampers DNA repair/ } \\
\text { methylation }\end{array}$ & $\begin{array}{l}\text { Same as folic acid, memory } \\
\text { loss }\end{array}$ & $\begin{array}{l}\text { Liver, sardines, salmon, clam, beef, milk, } \\
\text { cheese, yoghurt }\end{array}$ \\
\hline Vitamin B6 (Pyrido & & as folic acid & $\begin{array}{c}\text { Spinach, potato, bell peppers, turnip, } \\
\text { mushroom, garlic, cauliflower, } \\
\text { banana, chicken, pork, beef, salmon, } \\
\text { tuna, turkey }\end{array}$ \\
\hline Niacin (Vitamin B3) & Hampers DNA repair & Nerve problem, memory loss & $\begin{array}{l}\text { Pork, tuna, prawns, kidney, liver, } \\
\text { poultry, carrots, turnips and celery, } \\
\text { mushrooms, beans, almonds, wheat } \\
\text { products, rice bran, as well as milk } \\
\text { and other dairy products }\end{array}$ \\
\hline Vitamin C & Radiation mimics & $\begin{array}{c}\text { ulceration } \\
\text { disease scurvy, reflecting the } \\
\text { breakdown of connective } \\
\text { Cataract and cancer }\end{array}$ & \\
\hline Vitamin D (Calciferol) & Prevent gene variation & $\begin{array}{l}\text { Colon, breast, prostate } \\
\text { cancer }\end{array}$ & $\begin{array}{l}\text { Beef liver, cod liver oils, salmon, } \\
\text { mackerel, tuna, egg orange juice, } \\
\text { cow milk, yogurt, cheese }\end{array}$ \\
\hline Vitamin E (Tocopherols) & Mimics radiation & $\begin{array}{c}\text { damage Colon cancer, heart } \\
\text { disease, } \\
\text { immune dysfunction }\end{array}$ & $\begin{array}{l}\text { Tomato, spinach, broccoli, blueberries, } \\
\text { mangoes, kiwi, papaya, almonds, } \\
\text { hazelnuts, peanuts, wholegrain cereals } \\
\text { and vegetable oils }\end{array}$ \\
\hline Zinc & Chromosome breaks & $\begin{array}{l}\text { Brain and immune } \\
\text { dysfunction }\end{array}$ & $\begin{array}{l}\text { Oysters, beef, crab, pork, lobster, } \\
\text { chicken, spinach, broccoli, cashew } \\
\text { nuts, almond, milk, cheese, yogurt }\end{array}$ \\
\hline Iron & $\begin{array}{l}\text { DNA breaks and mimics } \\
\text { radiations }\end{array}$ & Anemia & \\
\hline Fatty acids & Alters gene expression & Obesity, CVD, Diabetes & $\begin{array}{c}\text { Salmon, sardines, } \\
\text { herring, mackerel, } \\
\text { soyoil, sunflower oil, palm oil, } \\
\text { flaxseeds, rapeseeds, peanuts, walnuts, } \\
\text { almonds, mustard seeds, cloves, } \\
\text { oregano, cauliflower, broccoli } \\
\end{array}$ \\
\hline Flavonoids & Alters gene expression & Cancer & $\begin{array}{l}\text { Onion, green bean, broccoli, curly kale, } \\
\text { endive, celery, cranberry, orange juice, } \\
\text { grape fruits, lemons, red, blue and purple } \\
\text { berries, peppers, tomatoes and eggplants }\end{array}$ \\
\hline Protein & Alters gene expression & Kwashiorkor, marasmus & $\begin{array}{l}\text { Egg, milk, soya milk, tofu, yoghurt, cheese, } \\
\text { broccoli, almonds, peanuts, cashew, poultry }\end{array}$ \\
\hline
\end{tabular}

Table 2: Nutrient deficiency diseases and preventive food sources (64Neeha VS and Priyamvadah Kinth, 2013).

*Food sources abundant in respective nutrients are only mentioned CVD Cardio Vascular Diseases. 


\section{Food Science and Nutrition Technology}

The real challenge for Nutrigenomics research is to target the genes those play a major role in the incidence of above mentioned common diet-related diseases. It is believed that the nutrition should focus primarily on health and disease prevention and be complementary to pharmacological therapy, which targets the pathophysiological aspects of disease. To realize this goal, new genomics-based phonotypical biomarkers are needed that allow early detection of the onset of disease. To approach this complex condition, molecular nutrition research on organ-specific dietary response patterns (using transgenic technology) is combined with genomic technologies [13]. Nutritional systems biology will take advantage of the combination of transcriptomic, proteomics and metabolomics, to identify molecular biomarkers. These biomarkers will allow early dietary intervention to reverse the onset of diet-related diseases and to regain homeostasis.

\section{Nutrigenomics and Biomarkers Development}

Nutrigenomics is a revolutionary approach, involves in finding markers of the early phase of diet related diseases; that is the phase at which intervention with nutrition can return the patient to health [65-67]. For the testing of efficacy of bioactive functional food ingredients, an urgent need exists for biomarkers.

Biomarkers are predominantly molecules associated with the pathways of metabolism, the proteins and are responsible for the metabolism of nutrients, as well as with the metabolites, derived from the relevant metabolic pathways. Biomarkers are the genetic variants that predict the risk of disease and improve diagnosis and risk assessment. Changes in a given metabolic pathway are associated with changes in the levels of gene expression (and thus - protein), and the content of a given metabolite. For example, a biomarker may be increased amount of blood sugar, which is a signal for glucose metabolism. A biomarker must meet certain criteria:

(i) Be associated with a pathological condition or disease;

(ii) Be easily measurable (eg in blood or urine);

(iii) Be modified by the intake of a food.

Markers can manipulate gene expression through use of nutrients or their combinations so as to improve productive as well as overall animal performance. By targeting specific genes through nutritional manipulation, it may be possible to get the desired human/livestock performance in terms of health as well as production [67].
Nutrigenomics practices for specific monogenic conditions such as PKU are currently being successfully used in health care interventions in the form of newborn screening programs. However, the inadequate success of single biomarkers in predicting chronic diseases attracts the need for different approaches or in other words thinking beyond the interaction of genes and nutrients. Moving from the single biomarkers to the other approaches is necessary because lowering the unilateral risk of one disease in an individual simply increases the risk of another disease in the same individual. Single nutrients may have multiple and unknown biochemical targets and physiological actions, which may not be easily addressed with chemical biomarkers [68]. The application of Nutrigenomics by healthcare professionals for the prevention and treatment of complex chronic diseases, however, has not yet been widely adopted.

Whether such practice will be feasible for the population-at-large in the immediate future remains to be determined, but the principles and tools of Nutrigenomics are expected to soon allow for earlier and more targeted interventions than currently exist [69]. As the current research in Nutrigenomics often focuses on how diet-gene interactions influence phenotypes found to be predictive biomarkers of disease $[70,71]$, it is likely that the path from research to applications will proceed into clinical practice using these markers of chronic disease as outcome measures. Recent developments in genome wide approaches have already identified many susceptibility alleles for common complex diseases, including several previously unknown etiologic pathways in disease pathogenesis [70], and have the potential to identify novel targets for prevention or treatment with dietary factors.

\section{Nutrigenomics Research Tools}

Because of the huge circulation of global trade and use of GM plant-derived food/feed stuff, progress needs to be made with definitive profiling techniques for the characterization of GM organism. The current improvements of new instruments have presented a tendency to use sensitive profiling technologies for the GM plants. The novel profiling tools will provide the evaluation of specific information of the metabolic pathways to detect unexpected effects in nutritionally improved GM crops.

The technical developments have given us novel tools enabling high-throughput genome-wide approaches, i.e. to provide meaningful interpretation for the assessment of GM crops as well as covering the entire human genome. 


\section{Food Science and Nutrition Technology}

The development of different 'omics' technologies (Genomics, Transcriptomic, Proteomics and Metabolomics, ionomics, foodomics etc) has created extraordinary opportunities for increasing our understanding about different cellular mechanisms like-

(i)Cellular, biochemical and molecular mechanisms underlies the beneficial or adverse effects of different bioactive components present in food;

(ii) in identifying the genes those may function as possible molecular biomarkers, and

(iii) The effect of bioactive components of food on vital molecular pathways.

Different genomic technologies, namely transcriptomic, proteomics, and metabolomics, are complementary in the types of information they generate, but are at different points in their development in this time. Ultimately, parallel use of these methods will allow us to describe the phenotype of a biological system. These tools form the basis of the biomics era. Genomics, transcriptomic, proteomics and metabolomics, together with bioinformatics, constitute the discipline functional genomics, which is also referred to as systems biology. Functional genomics aims to uncover both the functional roles of different genes and how these genes interact with, and/or influence each other in the functional network underlying health and disease.

Different Omics technology and nutrition, all the activities, are complementary to each other and parallel linked with human health. Exploitation of the relationship (Figure 4) among these technologies can provide us a complete understanding between food, nutrition and human health.

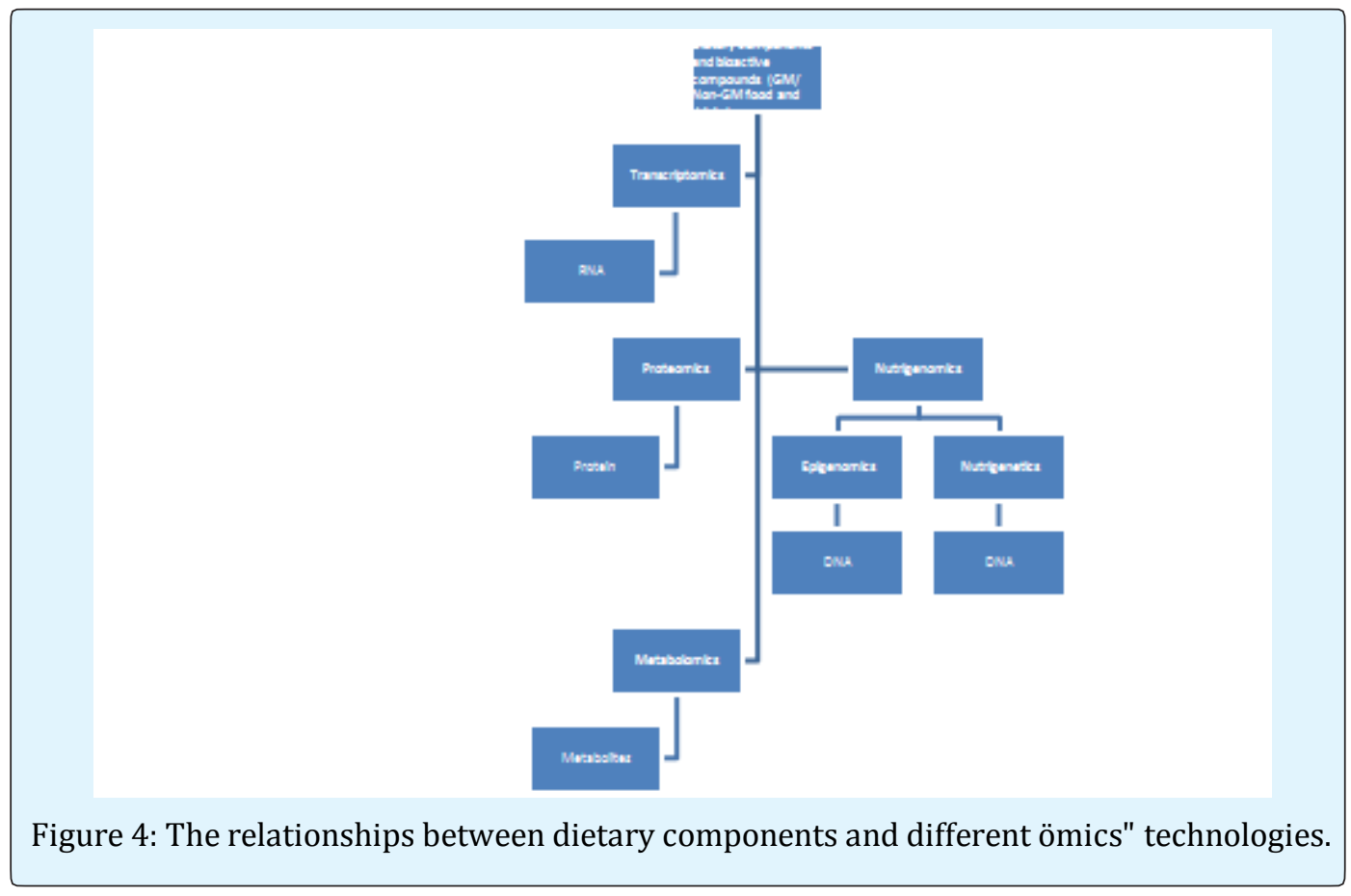

\section{Transcriptomics}

Transcriptomic is a relatively mature technology compared with other "-omics" technologies. Transcriptomic studies the complete set of activated RNA transcripts [72]. The mRNAs are produced by a given moment and in a given tissue of a selected organism; therefore, gene expression varies according to the different circumstances and periods of time [72,73].
The expression of genes can be evaluated at an unprecedented scale, using cDNA microarrays. These techniques are based on quantitative assay of the relative concentrations of specific mRNAs in tissue samples, which in turn reflects the level of gene regulation. This information can be used to examine the factors (including nutrients) that influence the key gene expression patterns. Although the mechanisms by which dietary 


\section{Food Science and Nutrition Technology}

components influence gene expression are poorly understood but it appears that transcription factors (TFs) are the main targets or nutrient sensors. Transcription factors, when activated, migrate to the nucleus and bind to a specific sequence of DNA in the promoter region of genes and, there, act by inhibiting or facilitating transcription $[73,74]$. These transcription factors can be stimulated by-

(i) Physiological signals, such as those triggered by nutrients/bioactive food compounds or the metabolites resulting from them;

(ii) Hormones, pharmacological treatments, and diseases, among others [73,75]. They act as sensors regulating/modulating transcription of the cells as needed [75].

In nutrition research, transcriptomics can assist in providing information about the mechanisms or underlying effects of a particular nutrient or diet. It can also help identifying genes, proteins, or metabolites that change in the state of predeceases, as well as assisting on recognizing and characterizing the pathways regulated by nutrients or bioactive compounds in foods $[72,73,75]$. The potential of transcriptomics will also help in providing relevant data for the monitoring of gene expression profiles of newly developed transgenic plant variety compared with its isogenic counterpart.

\section{Proteomics}

Proteins are an important class of molecules that are found in all living cells. They play a variety of roles in the cell such as structural, mechanical, biochemical, cell signaling, transport, and storage [76,77]. They are also an essential part of the human diet [76,77]. These proteins act in the cell, tissue, or organ in its normal state, but in different physiological or pathological situations, they may change their expression level, or even their activity $[72,73]$. Proteomics is the science that studies the complete set of proteins involved in the biological processes of a certain species [72]. But it is not yet possible to measure the whole proteome. The number of proteins produced by an organism is much larger than the number of genes that it possesses. This happens due to the numerous posttranscriptional/translational modifications.

However, research in proteomics is progressing rapidly [78]. Proteomics uses a set of technologies designed to study the expression of proteins. For this, it utilizes strategies, such as chromatographic techniques associated with electrophoresis, prefractionation of samples by extraction sequences, and organellar proteome analysis, etc [7374,76,79]. Studies of protein structure, expression level, cellular localization, biochemical activity, protein-protein interactions, and cellular roles are underway and considerable progress in novel instrumentation, experimental strategies, and bioinformatics methods has been achieved. Recent progress in this area is promising [78,80-82] and suggests that proteome-derived biomarkers useful in determining nutrition status may be identified before too long.

Hence, Proteomics is a primordial resource for Nutrigenomics, once that it is the gap between genome sequences and cell behavior, becoming the biological tool used to understand the process of genetic function determination, and of how genome is activated in response to certain diet $[73,74,76,79]$.

\section{Metabolomics}

Metabolomics is the area of functional genomics that studies the sum total of endogenous and exogenous metabolites in a cell, organ, or body fluids and also the changes in metabolites [76,83,84]. Metabolomics [85-90] it is a useful tool for generating individual metabolite profiles, such as complete plasma lipid (i.e, cholesterol, triglycerides) and vitamin profiles. Profiling of the plant metabolites, gene expression, and proteins may be helpful in detecting unexpected changes in GM organisms. Normally, natural variations may change large numbers of genes and proteins, thus many of those functions may not be estimated and the significance of such changes can be difficult to characterize.

Metabolomics is in the early stages of development. This technique is quite innovative, and validation of accuracy and sensitivity, especially in the predisease state, has yet to be explored. Scientists must first overcome a number of hurdles, such as full recovery of all metabolites from body fluids or tissue samples and the need to develop extensive databases with the required information about the nutritionally relevant metabolome. Metabolomics produces enormous amounts of data that require sophisticated instrumentation and software to allow researchers to extract meaningful information from the data. Existing instrumentation is quite sophisticated; the present limitations appear to be with the software needed to handle metabolomic data. The potential for nutritional applications of metabolomics is considerable, and a number of research teams are addressing these limitations. 


\section{Food Science and Nutrition Technology}

Metabolomics is already being applied in fundamental approaches aimed at gaining a better understanding of the interactive nature and control of important biochemical pathways in plants. It is providing novel information regarding the composition and potential nutritional imbalance of plant-based foodstuffs and is helping indicate how more tailor-made strategies could be designed to tackle key issues of global food quality in the highly contrasting situations typifying developing and developed countries.

Research advances in this area may facilitate the understanding of how the genotype is related to the phenotype of an individual. Nutritionally, metabolomics has many applications, once that it allows knowing the arrangements and metabolic disorders caused due to a person's diet and how these changes may affect the one's health or disease [73,76,83-84,91]. Hence, metabolomics also studies the metabolism under environmental and genetic perturbations [72] which can be analyzed and interpreted with the help of bioinformatics and statistical tools $[72,92]$.

The metabolites are dissolved in the cell cytosol and are small organic molecules that interact directly with the proteins and other macromolecules. They are divided into primary and secondary metabolites. Primery metabolites are directly involved with the routes of synthesis and degradation of macromolecules, while secondary metabolites are more common in plants and fungi, and act as structural components and their defense. The metabolites in living beings can act as substrates, such as inhibitors or activators of an enzyme, molecular precursors, wastes of synthesis, or degradation of macromolecules, among others.

In the area of nutrition, metabolomics allows the understanding of metabolic arrangements and instabilities that are the cause or suffer interference from the diet $[72,84]$. This contributes to the knowledge of how the excess or lack of some nutrients or compounds (secondary metabolites) present in food can affect the health/illness of an individual. These compounds (nutrients or not) interact in several ways within the body, changing the metabolome pathways. As an example, perilla alcohol (monoterpene extracted from strawberry) can act as an anticancer molecule under certain organic stimulations $[76,84]$.

\section{Conclusions and Future Prospect}

Nutrigenomics has emerged as a rapidly developing research area with great potential in modern plant science in both a fundamental and applied context and has quickly gained its place in the field of human nutrition and food. In addition, Nutrigenomics is beginning to pave the way for personalized nutrition as more associations between dietary components and gene regulations are being identified by this functional genomics approach. Moreover, through further understanding of the biological impacts of nutrient-gene modulations, Nutrigenomics will provide key insights into the pathogenesis and progression of diet-related disorders. A clear understanding of these interactions has the potential to support disease prevention through optimization of dietary recommendations. Though, the extent to which Nutrigenomics will be incorporated in nutrition therapy and promotion remains unknown.

However, in spite of fast progress, nutritional research has suffered from the incapability of delineating the mechanisms of diet-gene interactions. Identifying the genes needed to increase the levels of essential micronutrients in staple crops is an immediate goal that would have significant impact on human nutrition worldwide. Micronutrients malnutrition that exists in various population groups throughout the world could be reduced by a more nutritious food supply, especially if efforts are focused on staple crops such as rice, maize, wheat, beans and cassava. For essential minerals and vitamins that are limiting in the world diets, improvement strategies should be pursued keeping in mind the upper safe limits for each nutrient. Thus, the science of Nutrigenomics can be used to realize the pipedream of food security by maximizing human health through sustainable animal and plant agriculture.

\section{References}

1. FAO (2004) Agricultural Biotechnology: Meeting the needs of the poor? The State of Food and Agriculture, Rome: FAO.

2. Benkeblia N 2012 Mining Omic Technologies and Their Application to Sustainable Agriculture and Food Production Systems. in Benkeblia, N. (eds.)Sustainable Agriculture and New Biotechnology, London and New York: CRS Press - Tailor and Francis Group, 117-148.

3. James C (2014) ISAAA Report on Global Status of Biotech/GM Crops.

4. Yuan D, Bassie L, Sabalza M, Miralpeix B, Dashevskaya $S$, et al. (2011) Potential impact of plant 


\section{Food Science and Nutrition Technology}

biotechnology on the Millennium Development Goals. Plant Cell Rep 30(3): 249-265.

5. Zhu C, Naqvi S, Gomez-Galera S, Pelacho AM, Capell T, et al. (2007) Transgenic strategies for the nutritional enhancement of plants. Trends Plant Sci 12: 548-555.

6. Naqvi S, Farre G, Sanahuja G, Capell T, Zhu C, et al. (2009) When more is better: Multigene engineering in plants. Trends Plant Sci 15(1): 49-56.

7. Guillén ML, Sotos-Prieto M, Corella D (2012) Nutritional Genomics and Sustainable Agriculture. In Benkeblia, N. (eds.) Sustainable Agriculture and New Biotechnology, London and New York: CRS Press, Tailor and Francis Group 275-302.

8. Graham RD, Welch RM, Bouis HF (2001) Addressing micronutrient malnutrition through enhancing the nutritional quality of staple foods: principles, perspectives and knowledge gaps. Adv Agron 70: 77142.

9. Combs GF (2001) Selenium in global food systems. $\mathrm{Br}$ J Nutr 85(5): 517-547.

10. Monsen ER, Balintfy J (1982) Calculating dietary iron bioavailability: refinement and computerization. J Am Diet Assoc 80(4): 307-311.

11. Byrne P, Sarah W, Harrington J, Fuller L (2004) Transgenic Crops: An Introduction and Resource Guide. Department of Soil and Crop Sciences, Colorado State University.

12. Konig A, Cockburn A, Crevel RWR, Debruyne E, Grafstroem R, et al. (2004). Assessment of the safety of food derived from genetically modified GM crops. Food Chem Toxicol 42(7): 1047-1088.

13. Afman L, Muller M (2006) Nutrigenomics: from molecular nutrition to prevention of disease. J Am Diet Assoc 106: 569-576.

14. Ferguson LR (2006) Nutrigenomics: integrating genomic approaches into nutrition research. Mol Diagn Ther 10(2): 101-108.

15. Davidovich-Rikanati R, Sitrit Y, Tadmor Y, Iijima Y, Bilenko N, et al. (2007. Enrichment of tomato flavor by diversion of the early plastidial terpenoid pathway. Nat Biotechnol 25: 899-901.
16. Diretto G, Al-Babili S, Tavazza R, Papacchioli V, Giuliano G (2007) Metabolic engineering of potato carotenoid content through tuber-specific overexpression of a bacterial mini-pathway. PLoS ONE 2: e350.

17. Catchpole GS, Beckman M, Enot DP, Mondhe M, Zywicki B, et al. (2005) Hierarchical metabolomics demonstrates substantial compositional similarity between genetically modified and conventional potato crops. Proc Natl Acad Sci USA 102(40): 1445814462.

18. Dixon RA, Gang DR, Charlton AJ, Fiehn O, Kuiper H, et al. (2006) Applications of metabolomics in agriculture. J Agric Food Chem 54(24): 8984-8994.

19. Kutchan TM (2005) Predictive metabolic engineering in plants: still full of surprises. Trends in Biotechnol 23(8): 381-383.

20. Cruz IBM, Taufer M, Schwanke CHA (2003) Genomics in the era of aging and its potential application in gerontology and geriatrics. In: Institute of Geriatrics and Gerontology PUCRS: The Cradle of Academic Geriatrics In Brazil, Souza ACA, Ed., pp. 83-84, Pontifícia Universidade Católica do Rio Grande do Sul (EDIPUCRS), Porto Alegre, Brazil, 1st edition.

21. Vasconcelos FAG (2010) the science of nutrition in transit: from nutrition and dietetics to nutrigenomics. Revista de Nutricao 23(6): 935-945.

22. Fujii TMM, Medeiros R, Yamada R (2010) Nutrigenomics and nutrigenetics: important concepts for the science of nutrition. Nutrire: Journal of the Brazilian Society of Food and Nutrition 35(1): 149166.

23. Ghoshal S, Pasham S, Odom DB, Furr HC, McGrane MM (2003) Vitamin A depletion is associated with low phosphoenolpyruvate carboxykinase mRNA levels during late fetal development and at birth in mice. J Nutr 133: 2131-2136.

24. Menon B, Harinarayan CV, Raj MN, Vemuri S, Himabindu G, et al. (2010) Prevalence of low dietary calcium intake in patients with epilepsy: a study from South India. Neurol India 58: 209-212.

25. Gopalan C (1992) The contribution of nutrition research to the control of under nutrition: the Indian experience. Annu Rev Nutr 12: 1-17. 


\section{Food Science and Nutrition Technology}

26. Godbole K, Deshmukh U, Yajnik C (2009) Nutrigenetic determinants of neural tube defects in India. Indian Pediatrics 46(6): 467-475.

27. Rao S (2001) Nutritional status of Indian population. J Bioscience 26 (4): 481-489.

28. Naushad SM, Radha A, Devi R. 2010. Role of parental folate pathway single nucleotide polymorphisms in altering the susceptibility to neural tube defects in South India. J Perinat Med 38(1): 63-69.

29. Raj M, Sundaram KR, Paul Murli, Deepa AS, Kumar RK (2007) Obesity in Indian children: Time trends and relationship with hypertension. The National Medical Journal of India 20(6): 288-293.

30. Mohan V, Sandeep S, Deepa R, Shah B, Varghese C (2007) Epidemiology of type 2 diabetes: Indian scenario. Indian J Med Res 125(3): 217-230.

31. Mohan V, Sudha V, Radhika G, Radha V, Rema M, et al. (2007) Gene-environment interactions and the diabetes epidemic in India. Forum Nutr 60: 118 -126.

32. Lander ES, Linton LM, Birren B, Nusbaum C, Zody $\mathrm{MC}$, et al. (2001) Initial sequencing and analysis of the human genome. Nature 409: 860-921.

33. Peregrin $T$ (2001) the new frontier of nutrition science: Nutrigenomics. J Am Diet Assoc 101(11): 1306.

34. Fialho E, Moreno FS and Ong TPP (2008) Nutrition in the post-genomics: fundamentals and applications of omics tools. Journal of Nutrition 21(6): 757-766.

35. Norheim F, Gjelstad IMF, Hjorth M (2012) Molecular nutrition research-the modern way of performing nutritional science. Journal Nutrients 4(12): 18981944.

36. Muller M and Kersten S (2003) Nutrigenomics: goals and strategies. Nat Rev Genet 4(4): 315-322.

37. Kaput J, Ordovas JM and Ferguson I (2005) Nutritional genomics: the next frontier in the postgenomic era. Physiol Genomics 16(2): 166-177.

38. Kaput J, Ordovas JM, Ferguson L, van Ommen B, Rodriguez RL, et al. (2005) the case for strategic international alliances to harness nutritional genomics for public and personal health. British Journal of Nutrition 94(5): 623-632.
39. Mariman EC (2006) Nutrigenomics and nutrigenetics: the 'omics' revolution in nutritional science. Biotechnol. Appl. Biochem 44(3): 119-128.

40. Sales NMR, Pelegrini PB, and Goersch MC (2014) Nutrigenomics: Definitions and Advances of This New Science. Journal of Nutrition and Metabolism.

41. Wellen KE, Hotamisligil GS (2005) Inflammation, stress, and diabetes. J Clin Invest 115(5): 1111-1119.

42. Ronteltap A, van Trijp JCM, Renes RJ (2009) Consumer acceptance of Nutrigenomics-based personalised nutrition. British Journal of Nutrition 101(1): 132-144.

43. Cozzolino SMF (2012) The Bioavailability of Nutrients, Monole, São Paulo, Brazil, 4th edition.

44. Cozzolino SMF, Cominetti C (2013) Biochemical and Physiological Bases of Nutrition in Different Stages of Life in Health and Disease, Monole, São Paulo, Brazil, 1st edition.

45. Davis CD, Milner J (2004) Frontiers in nutrigenomics, proteomics, metabolomics and cancer prevention. Mutat Res 551(1-2): 51-64.

46. Trujillo E, Davis C, Milner J (2006) Nutrigenomics, proteomics, metabolomics, and the practice of dietetics. J Am Diet Assoc 106(3): 403-413.

47. Hu R, Kong AT (2004) Nutrition 20: 23-88.

48. German JB, Roberts MA, Watkins SM (2003) Genomics and metabolomics as markers for the interaction of diet and health: lessons from lipids. J Nutr 133(1): S2078-S2083.

49. German JB, Roberts MA, Watkins SM. 2003. Personal metabolomics as a next generation nutritional assessment. J. Nutr 133(42): 60-66.

50. Hisanori Kato (2008) Nutrigenomics: the cutting edge and Asian perspectives. Asia Pac J Clin Nutr 17 (S1): 12-15.

51. Hisanori Kato (2008) Nutrigenomics: the cutting edge and Asian perspectives. Asia Pac J Clin Nutr 17 (S1): 12-15.

52. Kaput J, Rodriquez RL (2004) Nutritional genomics: the next frontier in the postgenomic era. Physiol Genomics 16(2): 166-177. 


\section{Food Science and Nutrition Technology}

53. Corthésy-Theulaz I, den Dunnen JT, Ferré P, Geurts JMW, Müller M (2005) Nutrigenomics: the impact of biomics technology on nutrition research. Ann Nutr Metab 49(6): 355-265.

54. Ordovas JM (2006) Nutrigenetics, plasme lipids, and cardiovascular risk. J Am Diet Assoc 106(7): 10741081.

55. Go VLW, Nguyen CTH, Harris DM, Lee W-NP (2005) Nutrient-gene interaction: metabolic genotypephenotype relationship. J Nutr 135(12): 3016S3020S.

56. Mazzatti DJ, Ouderaa VD, Brown L (2007) the future of food: nutrigenomics and nutrigenetics. Agro Food Industries Hi-tech 18: 63-66.

57. International Life Sciences Institute (ILSI) (2004) Nutritional and safety assessments of foods and feeds nutritionally improved through biotechnology. Compr Rev Food Sci Safety 3: 35-104.

58. Newell-McGloughlin M (2008) Nutritionally Improved Agricultural Crops Plant Physiol 147(3): 939-953.

59. Kaput J, Ordovas J M, Ferguson L, van Ommen B, Rodriguez R L (2005) the case for strategic international alliances to harness nutritional genomics for public and personal health. Br J Nutr 94(5): 623-632.

60. Ray S (2014) Micronutrient, Genome Stability and Degenerative Diseases: Nutrigenomics Concept of Disease Prevention - An Overview. Curr Res Nutr Food Sci 2(3): 32- 44.

61. Helen Wallace (2006) Role of genes in diet- related diseases. In: Your Diet Tailored to Your Genes: Preventing Diseases or Misleading Marketing? A report by Gene Watch UK. The Mill House • Manchester Road - Tides well - Buxton Derbyshire SK17 8LN UK: 54-81.

62. Kim MK, Park JH (2009) Conference on "Multidisciplinary approaches to nutritional problems". Symposium on "Nutrition and health". Cruciferous vegetable intake and the risk of human cancer: epidemiological evidence. Proc Nutr Soc 68(1): 103-110.

63. He FJ, Nowson CA, MacGregor GA (2006) Fruit and vegetable consumption and stroke: meta-analysis of cohort studies. Lancet 367(9507): 320-326.
64. Neeha VS, Priyamvadah Kinth (2013) Nutrigenomics research: a review. J Food Sci Technol 50(3): 415-428.

65. Ramesha C, Kumari SS, Anuradha CM, Lakshmi H, Kumar CS (2010) Nutrigenomic analysis of mulberry silkworm (Bombyx mori L.) strains using Polymerase Chain Reaction - Simple Sequence Repeats (PCR-SSR). International Journal for Biotechnology and Molecular Biology Research 1(7): 92-100.

66. Lau FC, Bagchi M, Sen C, Roy S, Bagchi D (2008) Nutrigenomics analysis of diet-gene interactions on functional supplements for weight management. Curr Genomics 9(4): 239-251.

67. Kore KB, Pathak AK, Gadekar YP (2008) Nutrigenomics: emerging face of molecular nutrition to improve animal health and production. Vet world 1(9): 285-286.

68. Debusk RM, Fogarty CP, Ordovas JM, Kornman K S (2005) Nutritional genomics in practice: Where do we begin? J Am Diet Assoc 105(4): 589-598.

69. DeBusk R 2009 Diet-related disease, nutritional genomics, and food and nutrition professionals. J Am Diet Assoc 109(3): 410-413.

70. Kaput J, Noble J, Hatipoglu B, Kohrs K, Dawson K (2007) Application of nutrigenomic concepts to Type 2 diabetes mellitus. Nutr Metab Cardiovasc Dis 17(2): 89-103.

71. Ding K, Kullo IJ (2009) Genome-wide Association Studies for Atherosclerotic Vascular Disease and Its Risk Factors. Circ Cardiovasc Genet 2(1): 63-72.

72. Liu B, Qian SB (2011) Translational regulation in Nutrigenomics," American Society for Nutrition 2(6): 511-519.

73. Dalmiel L, Vargas T, Molina AR (2012) Nutritional genomics for the characterization of the effect of bioactive molecules in lipid metabolism and related pathways. Electrophoresis Journal 33(15): 22662289.

74. Costa NMB, Rosa COB (2011) Functional Foods: Bioactive Components and Physiological Effects. 1 Reprint, Rúbio, Rio de Janeiro, Brazil.

75. Fialho E, Moreno FS, Ong TPP (2008) Nutrition in the post-genomics: fundamentals and applications of omics tools. Journal of Nutrition 21(6): 757-766. 


\section{Food Science and Nutrition Technology}

76. Cozzolino SMF and Cominetti C (2013) Biochemical and Physiological Bases of Nutrition in Different Stages of Life in Health and Disease, Monole, São Paulo, Brazil, $1^{\text {st }}$ edition.

77. Sanhueza J and Valenzuela A (2012) Nutrigenomics: revealing the molecular aspects of a personalized nutrition. Chilean Journal of Nutrition 39(1): 1-12.

78. de Hoog CL, Mann M (2004) Proteomics. Annu Rev Genomics Hum Genet 5: 267-293.

79. Mahan LK, Stump S (2005) Food, Nutrition \& Diet Therapy, Roca, São Paulo, Brazil, 6th edition.

80. de Roos B, Duivenvoorden I, Rucklidge G, Reid M,Ross K, Lamers RJ, et al. (2005) Response of apolipoprotein E*3-Leiden transgenic mice to dietary fatty acids: Combining liver proteomics with physiological data. FASEB J 19(7): 813-815.

81. Okerberg ES, Wu J, Zhang B, Samii B, Blackford K (2005) High-resolution functional proteomics by active-site peptide profiling. Proc Natl Acad Sci USA 102(14): 4996-5001.

82. Chen JH, Chang YW, Yao CW, Chiueh TS, Huang SC (2004) Plasma proteome of severe acute respiratory syndrome analyzed by two-dimensional gel electrophoresis and mass spectrometry. Proc Natl Acad Sci U S 101(49): 17039-17044.

83. Rocha TLR, Evaristo RGS, Silva LP. 2006. Metabolomics: Applications and Perspectives, EMBRAPA, Brasilia, Brazil, $1^{\text {st }}$ edition.

84. Ronteltap A, van Trijp JCM, Renes RJ (2009) Consumer acceptance of nutrigenomics-based personalised nutrition. British Journal of Nutrition 101(1): 132-144.

85. van Ommen B, Stierum R (2004) Nutrigenomics: Exploiting systems biology in the nutrition and health arenas. Nutrition 13(5): 517-521.

86. Davis CD and Milner J (2004) Frontiers in nutrigenomics, proteomics, metabolomics and cancer prevention. Mutat Res 551(1-2): 51-64.

87. Dunn WB, Bailey NJ and Johnson HE (2005) Measuring the metabolome: Current analytical technologies. Analyst 130(5): 606-625.

88. German JB, Bauman DE, Burrin DG, Failla ML, Freake $\mathrm{HC}$, et al. (2004) Metabolomics in the opening decade of the 21st century: Building the roads to individualized health. J Nutr 134(10): 2729-2732.

89. German JB, Roberts MA and Watkins SM (2003) Genomics and metabolomics as markers for the interaction of diet and health: lessons from lipids. J Nutr 133(6): S2078-S2083.

90. German JB, Roberts MA, Watkins SM (2003) Personal metabolomics as a next generation nutritional assessment. J. Nutr 133(42): 60-66.

91. Ong TP, Rogero MM (2009) Nutrigenomics: importance of nutrient-gene interaction for health promotion. Journal of the ABESO.

92. Norheim F, Gjelstad IMF, Hjorth M (2012) Molecular nutrition research-the modern way of performing nutritional science. Switzerland. Journal Nutrient 4(12): 1898-1944. 